\title{
Analysis of Mars analogue soil samples using solid-phase microextraction, organic solvent extraction and gas chromatography/mass spectrometry
}

\author{
G. E. Orzechowska', R. D. Kidd', B. H. Foing' ${ }^{2}$ I. Kanik', C. Stoker ${ }^{3}$ \\ and P. Ehrenfreund ${ }^{4,5}$ \\ ${ }^{1}$ Jet Propulsion Laboratory, California Institute of Technology, Pasadena, CA 91109, USA \\ e-mail: Richard.D.Kidd@jpl.nasa.gov \\ ${ }^{2}$ European Space Agency (ESA), ESTEC SRE-S, Postbus 299, 2200AG Noordwijk, The Netherlands \\ ${ }^{3}$ NASA Ames Research Center, Moffett Field, CA 94035, USA \\ ${ }^{4}$ Space Policy Institute, George Washington University, Washington 20052, USA \\ ${ }^{5}$ Leiden Institute of Chemistry, Leiden University, 2300 RA Leiden, The Netherlands
}

\begin{abstract}
Polycyclic aromatic hydrocarbons (PAHs) are robust and abundant molecules in extraterrestrial environments. They are found ubiquitously in the interstellar medium and have been identified in extracts of meteorites collected on Earth. PAHs are important target molecules for planetary exploration missions that investigate the organic inventory of planets, moons and small bodies. This study is part of an interdisciplinary preparation phase to search for organic molecules and life on Mars. We have investigated PAH compounds in desert soils to determine their composition, distribution and stability. Soil samples (Mars analogue soils) were collected at desert areas of Utah in the vicinity of the Mars Desert Research Station (MDRS), in the Arequipa region in Peru and from the Jutland region of Denmark. The aim of this study was to optimize the solid-phase microextraction (SPME) method for fast screening and determination of PAHs in soil samples. This method minimizes sample handling and preserves the chemical integrity of the sample. Complementary liquid extraction was used to obtain information on five- and six-ring PAH compounds. The measured concentrations of PAHs are, in general, very low, ranging from 1 to $60 \mathrm{ng} \mathrm{g}^{-1}$. The texture of soils is mostly sandy loam with few samples being $100 \%$ silt. Collected soils are moderately basic with $\mathrm{pH}$ values of 8-9 except for the Salten Skov soil, which is slightly acidic. Although the diverse and variable microbial populations of the samples at the sample sites might have affected the levels and variety of PAHs detected, SPME appears to be a rapid, viable field sampling technique with implications for use on planetary missions.
\end{abstract}

Received 30 November 2010, accepted 10 December 2010, first published online 20 January 2011

Key words: chromatography, gas chromatograph/mass spectrometer (GC/MS), Mars, polycyclic aromatic hydrocarbons (PAHs), solid-phase microextraction (SPME).

\section{Introduction}

The question of whether life arose on Mars has been widely discussed in the planetary community, partially because the conditions in its early history may have resembled those of the early Earth (McKay 1997). However, the current harsh conditions on Mars, including energetic ultraviolet (UV) radiation, extreme dryness and the presumed oxidizing nature of the soil, are destructive to any organic material that is or was exposed to the Martian surface (Zent \& McKay 1994; Benner et al. 2000). Although no organic material could be identified with the Viking Mars landers three decades ago (Biemann et al. 1976; Biemann \& Lavoie 1979), several space missions will visit the Martian surface in the coming decade to search for organic compounds as well as extinct and extant life. In this context, it is vital to obtain knowledge about the survival of organics in extreme conditions. Measuring the abundance and distribution of organic matter in Mars analogue samples collected in dry deserts is critical to our understanding of preservation.

Polycyclic aromatic hydrocarbons (PAHs) are among the most abundant organic molecules in space environments (Tielens 2008). Their high abundance and resistance to radiation and thermal degradation make them a key target in the search for organic material in the solar system. PAHs reach planetary surfaces through the impacts of small solar system bodies (Sephton \& Botta 2005). Naphthalene, phenanthrene, pyrene and chrysene, for instance, have been found in the ALH84001 meteorite (McKay et al. 1996). PAHs are considered to be ubiquitous in terrestrial environments (Edwards 1983) and they originate from both natural and anthropogenic sources. PAHs are composed of polymerized six-member benzene rings and are probably the largest and the most structurally diverse class of organic compounds. The diversity of PAHs is caused in part by alkylation, mostly 
Table 1. Martian soil analogues analysed in this study; sampling locations, pH, texture and organic mass loss of the soil samples

\begin{tabular}{|c|c|c|c|c|c|c|c|c|c|c|c|}
\hline \multirow{2}{*}{$\begin{array}{l}\text { Short } \\
\text { name }\end{array}$} & \multirow[b]{2}{*}{ Location } & \multirow[b]{2}{*}{ Coordinates } & \multirow[b]{2}{*}{ Altitude } & \multirow[b]{2}{*}{ Depth } & \multirow[b]{2}{*}{ Formation } & \multirow[b]{2}{*}{ Colour } & \multirow[b]{2}{*}{$\mathrm{pH}$} & \multicolumn{3}{|c|}{$\begin{array}{l}\text { Texture of soil } \% \text { of } \\
\text { each layer* }\end{array}$} & \multirow{2}{*}{$\begin{array}{l}\text { Organic } \\
\text { matter } \\
(\% \mathrm{w} / \mathrm{w})\end{array}$} \\
\hline & & & & & & & & Sand & Silt & Clay & \\
\hline $\mathrm{P}-1$ & Utah, USA & $\begin{array}{l}\mathrm{N} 38.43621^{\circ} \\
\mathrm{W} 110.81943^{\circ}\end{array}$ & $1350 \mathrm{~m}$ & surface & $\begin{array}{l}\text { Mancos Shale/ } \\
\text { Tunuck }\end{array}$ & Grey & $8.37-7.77$ & 10 & 90 & & 2 \\
\hline P-2 & Utah, USA & $\begin{array}{l}\mathrm{N} 38.40746^{\circ} \\
\mathrm{W} 110.79280^{\circ}\end{array}$ & $1382 \mathrm{~m}$ & surface & Morrison & White & $8.93-8.11$ & & 100 & & 1 \\
\hline P-3 & Utah, USA & $\begin{array}{l}\mathrm{N} 38.40737^{\circ} \\
\mathrm{W} 110.79261^{\circ}\end{array}$ & $1375 \mathrm{~m}$ & surface & Morrison & $\begin{array}{r}\text { Beige } \\
\text { pink }\end{array}$ & $9.15-8.33$ & 25 & 75 & & 1 \\
\hline P-5 & Utah, USA & $\begin{array}{l}\mathrm{N} 38.42638^{\circ} \\
\mathrm{W} 110.78342^{\circ}\end{array}$ & $1400 \mathrm{~m}$ & cliff & Morrison & $\begin{array}{r}\text { Rusty } \\
\text { pink }\end{array}$ & $9.28-8.88$ & 25 & 25 & 50 & 2 \\
\hline P-6 & Utah, USA & $\begin{array}{l}\mathrm{N} 38.42638^{\circ} \\
\mathrm{W} 110.78342^{\circ}\end{array}$ & $1400 \mathrm{~m}$ & cliff & Morrison & Beige & $8.37-7.56$ & 25 & & 75 & 2 \\
\hline P-7 & Utah, USA & $\begin{array}{l}\mathrm{N} 38.45424^{\circ} \\
\mathrm{W} 110.79092^{\circ}\end{array}$ & $1357 \mathrm{~m}$ & surface & Morrison & $\begin{array}{l}\text { Grey } \\
\text { pink }\end{array}$ & $10.01-8.97$ & 45 & 45 & 10 & 2 \\
\hline P-8 & Utah, USA & $\begin{array}{l}\mathrm{N} 38.43755^{\circ} \\
\mathrm{W} 110.88725^{\circ}\end{array}$ & $1482 \mathrm{~m}$ & surface & Mancos Shale & $\begin{array}{l}\text { Light } \\
\text { brown }\end{array}$ & $8.22-7.55$ & & 100 & & 4 \\
\hline P-10 & Utah, USA & $\begin{array}{l}\mathrm{N} 38.43896^{\circ} \\
\mathrm{W} 110.89001^{\circ}\end{array}$ & $1500 \mathrm{~m}$ & surface & Mancos Shale & Grey & $8.42-7.60$ & 50 & 50 & & 5 \\
\hline P-13 & Utah, USA & $\begin{array}{l}\mathrm{N} 38.40630^{\circ} \\
\mathrm{W} 110.79547^{\circ}\end{array}$ & $1405 \mathrm{~m}$ & surface & Dakota & $\begin{array}{r}\text { Light } \\
\text { grey }\end{array}$ & $8.75-7.41$ & 80 & 10 & & 2 \\
\hline P-14 & Utah, USA & $\begin{array}{l}\mathrm{N} 38.40630^{\circ} \\
\mathrm{W} 110.79547^{\circ}\end{array}$ & $1405 \mathrm{~m}$ & $15 \mathrm{~cm}$ & Dakota & $\begin{array}{l}\text { Light } \\
\text { brown }\end{array}$ & $8.21-7.56$ & 40 & 40 & 20 & 3 \\
\hline НОво & $\begin{array}{l}\text { Arequipa, } \\
\text { Peru }\end{array}$ & $\begin{array}{l}\text { S16.44345 } \\
\text { W72.02367 }\end{array}$ & & & & $\begin{array}{l}\text { Rusty } \\
\text { brown }\end{array}$ & $7.18-7.04$ & 50 & 50 & & 1 \\
\hline $\begin{array}{l}\text { Salten } \\
\text { SKOV }\end{array}$ & Denmark & & & & & $\begin{array}{l}\text { Red } \\
\text { brown }\end{array}$ & $6.01-5.89$ & & 100 & & 12 \\
\hline
\end{tabular}

*The preliminary soil analysis in this table employed a less sophisticated technique than that used in Kotler et al. 2011.

methylation (attachment of $-\mathrm{CH}_{3}$ groups) (Zolotov \& Shock 1999). The Gibbs energetic paths of PAH formation from pyrolysis, oxidation and dehydrogenation of other hydrocarbons are favourable, with dehydrogenation being the common path for PAH production from biogenic organic compounds. The complexity and diversity of environmental contaminants such as PAHs have resulted in the development of many different analytical techniques and protocols for their extraction and analysis. Analysis of organic compounds (including $\mathrm{PAHs}$ ) in the environment often requires tedious sampling to achieve a proper picture of the level of contamination, and the complex matrices of soil samples have always been laborious to analyse. A liquid extraction may require large volumes of highpurity organic solvents, which must then be disposed of. Some of the more volatile substances may be lost during processing of the samples. With numerous sources of possible systematic errors inherent to complex analytical procedures, much of today's research is aimed at faster extractions, analysis methods and techniques for fast screening and field analysis.

Here we report the extraction and abundance measurements of PAHs from Mars soil analogues using solid-phase microextraction (SPME) and liquid extraction methods. SPME is a solvent-free extraction method invented by Pawliszyn (Berlardi \& Pawliszyn 1989; Pawliszyn 1999) and applied in a variety of sampling-detection scenarios (Grote \& Pawliszyn 1997; Pawliszyn \& Martos 1997; Jia et al. 2000; Kataoka et al. 2000; Lord \& Pawliszyn 2000; Pawliszyn 2000; Wu et al. 2000; Orzechowska \& Paulson 2005). When compared with traditional extraction methods, SPME may provide better analyte recoveries, less opportunity for rearrangement and decomposition of analytes, and faster analysis. Headspace analysis is a suitable method to determine volatile/semivolatile substances directly without chemical pretreatment of samples. We compare the analysis of PAHs in Mars soil analogues using SPME and liquid extraction methods and investigate PAH abundance and distribution in relation to soil properties.

\section{Soil analogue samples and their geological context}

Analogue samples had been collected in the vicinity of the Mars Desert Research Station (MDRS) by Crew 77 in February 2009 from different site locations (Table 1 and Fig. 1) as part of the EuroGeoMars campaign. Soils come from four geologic successions. In stratographic order, these are:

- Mancos Shale, Blue gate member

- Mancos Shale, Tununk member

- Dakota Sandstone

- Formation Bushy Basin member

The Bushy Basin member-the first representative of the Morrison Formation in the area - was deposited in a massive flood plain (Williams \& Hackman 1971; Fillmore 2000). As the flooding waned, phyllosilicate and bentonite-rich shale were deposited on a massive mudflat that was occasionally cut by eastward-flowing streams. Sparse units of white, relatively finegrained sandstone and brownish conglomerate record the passage of these streams through the mudflats. The Morrison 


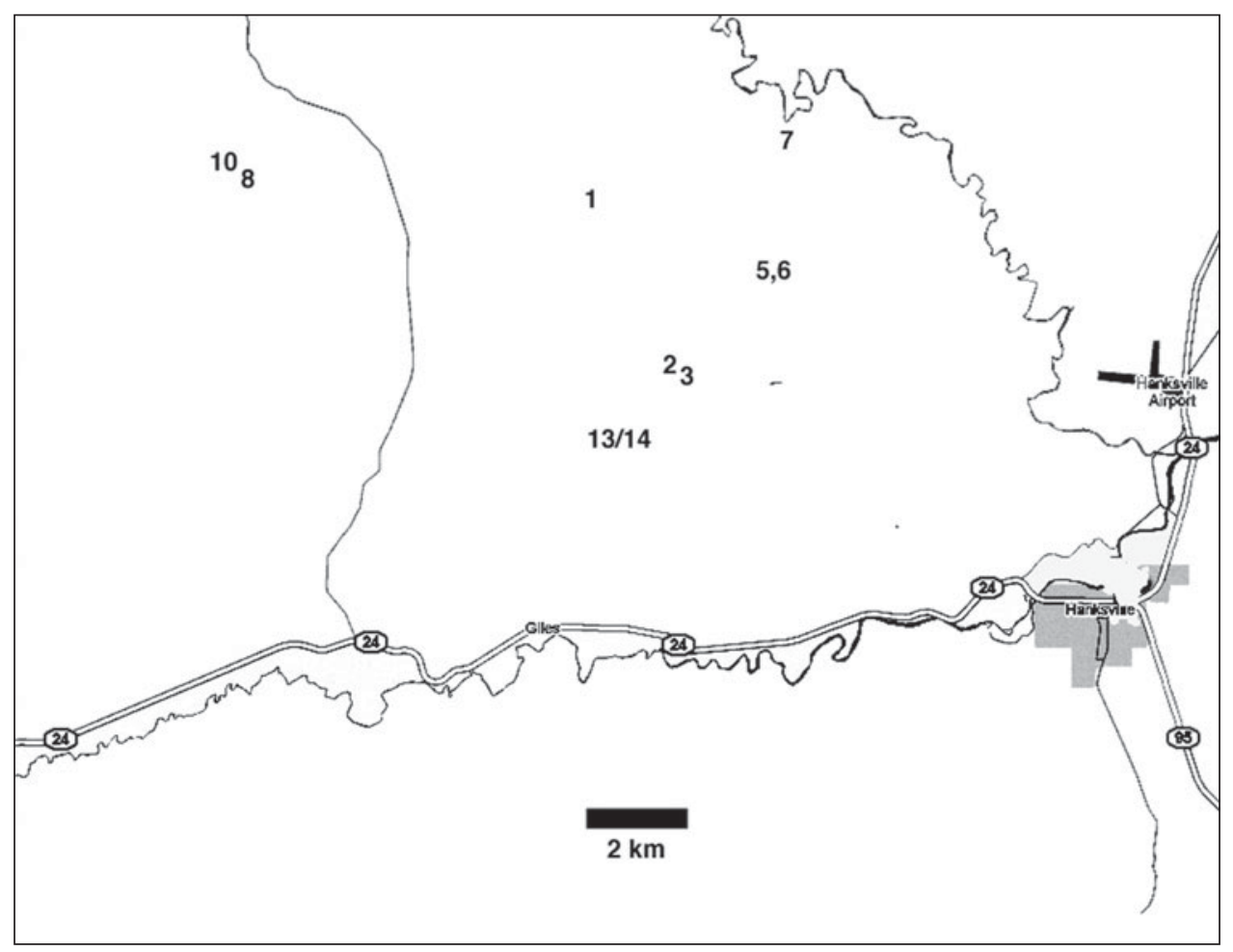

Fig. 1. Map illustrating locations where soil samples were collected in the vicinity of Hanksville, Utah, February 2009. The exact positions of samples are in Table 1.

Formation unit was deposited in the late Jurassic epoch and is fossiliferous, containing dinosaur remains in some locations. In the MDRS area, the Morrison Formation mudflats form rounded hills with a finely fractured bentonite surface resembling popcorn. The colourful hills exhibit outcrops of red, brown, purple and greyish-green layers on a dominantly buff-coloured base. The streambeds that transected the mudflats form prominent stacks, often capped with a conglomerate layer. Some examples of these form complete inverted streambed successions. Cross-bedded features are common with alternating lenses of fine-grained sandstone and conglomerates, reflecting the different flow velocities at different times. The fine-grained sandstones often contain round concretions 3-5 mm in diameter. The Dakota Sandstone caps sections of the Morrison Formation but is discontinuous in the MDRS area. This sandstone was deposited in the early Cretaceous period and constitutes the ancient marine shoreline of a seabed, with evidence of tidal currents and large agglomerations of fossil seashells (samples P-13 and P-14 were collected from the top of the hill above MDRS that contains shells down to $10 \mathrm{~cm}$ ). Samples P-2 and P-3 are from the Morrison Formation/Dakota Sandstone boundary and soils may be derived from some mixture of these units. The Mancos Shale, deposited in a deep sea during the Cretaceous period, is up to $3000 \mathrm{ft}$ thick and is dramatically exposed in the Factory Butte area where samples P-8 and P-10 were collected. The record shows four large-scale, sea-level fall and rise cycles. The Tununk member of the Mancos Shale was deposited in the deep reaches of a seaway, far from shore where a thick pile of black ooze accumulated. The Tununk was deposited as the sea deepened, whereas deposition of the Ferron Sandstone took place as the sea withdrew. In the next marine transgression, the Blue gate member of the Mancos Shale was deposited. Again, this was a deep-sea depositional environment where carbonrich black ooze was deposited. The Mancos Shale is very rich in sulfides, which have weathered to sulfate near the surface. In many locations, gypsum crystals form on the surface of the soils and large $(10-30 \mathrm{~cm})$ concretions of gypsum are found embedded in the walls of the buttes.

The HOBO sample was collected from the Atacama Desert in the Arequipa region of southern Peru at an altitude of $1165 \mathrm{~m}\left(\mathrm{~S} 16^{\circ} 44^{\prime} 34.7^{\prime} \mathrm{W} 72^{\circ} 02^{\prime} 37.9^{\prime}\right)$. Anorthite has been identified as the dominating mineral in this sample and a low $\mathrm{CaSO}_{4}$ content $(5 \%)$ was measured. The samples are organic poor and contain only a very low amount of amino acids (Peeters et al. 2009).

A Salten Skov sample had been obtained from the Jutland region in Denmark. The Salten Skov sediment had been selected as a Mars analogue by Merrison et al. (2004) to study wind speed and orientation with respect to electrical charges and gravity on Mars. It is a natural sedimentary soil, extremely fine grained and containing a high concentration of various iron oxides (over $60 \%$ by weight). It is mainly composed of goethite with $5.5 \mathrm{wt} \%$ maghaemite and $12.8 \mathrm{wt} \%$ haematite (Nornberg et al. 2004). Fresh Salten Skov samples have been reported to contain $1.5 \times 10^{6} \mathrm{CFU} \mathrm{g}^{-1}$ under aerobic conditions (Hansen et al. 2005). Properties of Salten Skov have been extensively discussed in Seiferlin et al. (2008). 


\section{Experimental section}

All soil samples were stored in sterile low-density polyethylene bags. PAHs of interest are shown in Table 2.

\section{Soil texture $\mathrm{pH}$ and organic matter content}

A simple texture test was performed on each soil sample (using about $1 \mathrm{~g}$ for each). Samples were placed in glass vials and high-performance liquid chromatograph (HPLC)-grade water (Burdick \& Jackson) was added to three-fourths of the vial volume and then capped. Samples were shaken vigorously for 2 min to bring soil particles into suspension in the water. The sample was allowed to settle for about $1 \mathrm{~min}$ and the top of the layer that settled was marked. This layer is comprised primarily of sand and larger particles. After $1 \mathrm{~h}$ of settling, the next layer (silt) was marked. Samples were then left to settle for $24 \mathrm{~h}$ and the last settled layer (clay) was marked. The percentage of each layer was then calculated (Table 1).

The $\mathrm{pH}$ of each soil sample was measured using an Accumet Excel XL20 pH meter (Fisher Scientific). Measurements were performed with samples that had been examined for soil texture after the soils had been soaked in water for $24 \mathrm{~h}$ and then again after 2 weeks (Table 1).

The amount of organic material was determined by placing weighed, dried $\left(24 \mathrm{~h}\right.$ at $\left.105^{\circ} \mathrm{C}\right)$ soil samples in an oven heated to $600^{\circ} \mathrm{C}$ for $24 \mathrm{~h}$. The organic matter in soil is evaporated as gases $\left(\mathrm{CO}_{2}\right.$ and $\left.\mathrm{H}_{2} \mathrm{O}\right)$ resulting in a change of the sample weight, which enabled calculations of the organic content of the soil sample (Table 1).

\section{Chemicals and materials}

Liquid standards were purchased from Supelco (SigmaAldrich): PAHs standard, $2000 \mu \mathrm{g} \mathrm{ml}^{-1}$ in dichloromethane: benzene (1:1); 4-terphenyl- $\mathrm{d}_{14}, 2000 \mu \mathrm{g} \mathrm{ml}^{-1}$ in dichloromethane; perylene- $\mathrm{d}_{12}, 2000 \mu \mathrm{g} \mathrm{ml}^{-1}$ in dichloromethane; anthracene- $\mathrm{d}_{10}, 2000 \mu \mathrm{g} \mathrm{ml}^{-1}$ in dichloromethane; and benz [e]pyrene, $100 \mu \mathrm{g} \mathrm{ml}^{-1}$ in cyclohexane. Stock and diluted solutions of standards were prepared in a 1:1 mixture of dichloromethane:hexane.

Certified soil materials: Soil standard BCR-524 (Supelco 2008) used in this study was collected from a creosotecontaminated area. It contains relatively high levels of PAHs, including several PAHs not certified in this standard, and also contains a low level of PCP (pentachlorophenol). Loamy sand (CRM 171-050), clay (CRM 170-050) and sediment (CRM 104-100) soil standards were purchased from Resource Technology Corporation, Laramie, WA. The levels of PAHs in the soil standards are shown in Table 3.

Chemicals used with the liquid extraction procedure: Gas chromatograph/mass spectrometer (GC/MS)-grade dichloromethane (Across Organics), HPLC-grade hexane and LC/MSgrade methanol (Burdick \& Jackson) were all purchased from VWR, and activated silica gel for column chromatography, $60-200 \mu \mathrm{m}, 60 \AA$ (Across Organics), was purchased from Fisher-Scientific.

SPME device and fibres: A Supelco SPME device containing a syringe-like holder with a stainless-steel needle was purchased from Sigma-Aldrich. Analytes are absorbed into a thin polymer phase, which had been deposited onto a silica fibre housed in a syringe needle. Sampling is accomplished by penetrating the septum of a reaction vessel with the syringe needle, depressing the plunger and exposing the fibre to the target mixture. The fibre is allowed to absorb the analytes for a specified time, after which the needle containing the fibre is withdrawn and then inserted into a hot GC injector, desorbing the analytes in splitless mode for GC/MS analysis. The selection of a fibre is based on overall fibre performance and compatibility with target analytes. A manual SPME device with a $100 \mu \mathrm{m}$ polydimethylsiloxane (PDMS)-coated fibre was chosen for all experiments. A $30 \mu \mathrm{m}$ fibre was also tested. Although the $30 \mu \mathrm{m}$ fibre had the better desorption efficiency, the $100 \mu \mathrm{m}$ fibre provided a better response because of the higher extraction levels. We noticed approximately 3-fold higher sampling efficiencies for the $100 \mu \mathrm{m}$ compared to the $30 \mu \mathrm{m}$ PDMS fibres for naphthalene through fluorene and $15 \times$ higher efficiencies for phenanthrene and larger PAHs under similar sampling conditions. The biggest drawbacks of using the $100 \mu \mathrm{m}$ vs. $30 \mu \mathrm{m}$ fibres for large semi-volatile compounds are the longer equilibration times and an increased risk for carryover (more difficult to completely desorb analytes from the fibres between runs) due to the high affinity for the stationary phase. To eliminate carryover the fibre was left in the hot injection port for the entire GC run.

\section{Procedure of liquid extraction with organic solvents}

Extractions were performed on soil samples (on average $3.1 \mathrm{~g}$ ), certified reference material (CRM) standard soils $(1 \mathrm{~g}$ on average), BCR-524 standard soil ( $0.3 \mathrm{~g}$ on average) and liquid standard (48905-U, diluted in 1:1 dichloromethane:hexane) to obtain $2 \mathrm{ng}^{-1}$ concentration in the final volume of the extract $(250 \mu \mathrm{l})$. A mixture of $5 \mathrm{ml}$ dichloromethane:methanol (93:7, v/v) was added to samples placed in Kimble test tubes with screw caps. Then a surrogate $\mathrm{PAH}$, anthracene- $\mathrm{d}_{10}$ (diluted in 1:1 dichloromethane:hexane, v/v), was added to the mixtures to obtain a final concentration of $2 \mathrm{ng}^{-1} \mathrm{l}^{-1}$ in the extraction volume. The mixtures were shaken for $2 \mathrm{~min}$ and then extracted thrice using a sonication bath for $25 \mathrm{~min}$ at $25^{\circ} \mathrm{C}$.

After each extraction the sample was centrifuged for $15 \mathrm{~min}$ at $90 \mathrm{rpm}$ and then the liquid phase was transferred to a Pyrex test tube using a Pasteur pipette. The collected extracts were evaporated almost to dryness $(<0.5 \mathrm{ml}$ sample left) using a model RC 1022 (Jouan Inc.) desktop vacuum concentrator or in a stream of dry nitrogen gas. We did not notice significant differences in extraction efficiencies for samples dried under either condition. The vacuum concentrator, however, allows faster sample processing. Around $40 \mathrm{mg}$ of activated silica was added to each test tube and allowed to dry under nitrogen. Then the dried silica + sample was transferred onto a column filled with about $0.8 \mathrm{~g}$ of activated silica. The columns had been previously prepared using long-stem Pasteur pipettes with a small piece of quartz wool placed on the bottom of the pipette column to stabilize the silica bed in the column. The columns were rinsed with $5 \mathrm{ml}$ of hexane before the sample was transferred onto the column. Organics were eluted using a sequence of the following solvents: hexane $(1 \mathrm{ml}), 1: 1$ 
Table 2. Chemical structure, quantitation and confirmation ions of PAHs analysed by GC/MS. Compound are listed in the order they eluted from the column

\begin{tabular}{|c|c|c|c|c|c|c|c|c|c|c|c|}
\hline Compound & $\begin{array}{l}\text { Chemical } \\
\text { structure }\end{array}$ & Quant. ion & Conf. ion & Compound & Chemical structure & Quant. ion & $\begin{array}{l}\text { Conf. } \\
\text { ion }\end{array}$ & Compound* & $\begin{array}{l}\text { Chemical } \\
\text { structure }\end{array}$ & Quant. ion & Conf. ion \\
\hline Naphthalene & & 128 & 127 & 4-Terphenyl-d ${ }_{14}$ (ISTD) & & 244 & & Dibenzo[a,h]anthracene & & 278 & 139 \\
\hline Acenaphthylene & & 152 & 151 & Benz[a]anthracene & & 228 & 114 & Benzo[g,h,i]perylene & & 276 & 138 \\
\hline Acenaphthene & & 154 & 153 & Chrysene & & 228 & 114 & & & & \\
\hline Fluorene & & 166 & 165 & Benzo[k]fluoranthene & & 252 & 126 & & & & \\
\hline Phenanthrene & & 178 & 176 & Benzo[b]fluoranthene & & 252 & 126 & & & & \\
\hline $\begin{array}{l}\text { Anthracene- } \\
\mathrm{d}_{10}(\text { surrogate })\end{array}$ & & 188 & & Benzo[a]pyrene & & 252 & 126 & & & & \\
\hline Anthracene & & 178 & 176 & Benzo[e]pyrene & & 252 & & & & & \\
\hline Fluoranthene & & 202 & 101 & Perylene-d $\mathrm{d}_{12}$ (ISTD) & & 264 & & & & & \\
\hline Pyrene & & 202 & 101 & Indeno[1,2,3-sd] pyrene & & 276 & 138 & & & & \\
\hline
\end{tabular}

*As is standard practice, the compounds are ordered via ascending levels of the quantification ions. This order was kept for Tables 3-5. 
Table 3. Certified amounts of PAH in CRM standard (Resource Technology Corporation, Laramie, WA, 2009) and BCR-524 (ATSDR 1995) soil samples

\begin{tabular}{|c|c|c|c|c|c|}
\hline Compound & $\begin{array}{l}\text { CRM 171-050 } \\
\text { Loamy sand } \\
\mathrm{pH} 5.35 \\
\left(\mathrm{ng} \mathrm{g}^{-1}\right)\end{array}$ & $\begin{array}{l}\text { CRM 170-050 } \\
\text { Clay pH } 7.40 \\
\left(\mathrm{ng} \mathrm{g}^{-1}\right)\end{array}$ & $\begin{array}{l}\text { CRM 104-100 } \\
\text { Sediment + pH } 8.12 \\
\left(\mathrm{ng} \mathrm{g}^{-1}\right)\end{array}$ & $\begin{array}{l}\text { BCR-524 } \\
\text { pH } 6.95 \\
\left(\mathrm{ng} \mathrm{g}^{-1}\right)\end{array}$ & $\left(\mu \mathrm{g} \mathrm{g}^{-1}\right)$ \\
\hline Naphthalene & 223 & 367 & 565 & & \\
\hline Acenaphthylene & 112 & 83.6 & & & \\
\hline Acenaphthene & 133 & 269 & 544 & & \\
\hline Fluorene & 131 & 342 & 626 & & \\
\hline Phenanthrene & 387 & 707 & 4660 & & \\
\hline Anthracene & 28 & 222 & 365 & & \\
\hline Fluoranthene & 213 & 146 & 9200 & & \\
\hline Pyrene & 177 & 163 & 7430 & 173000 & 173 \\
\hline Benz[a]anthracene & 86 & 59.7 & 5410 & 22500 & 22.5 \\
\hline Chrysene & 181 & 128 & 6590 & & \\
\hline Benzo[b]fluoranthene & 138 & 193 & 5220 & 13500 & 13.5 \\
\hline Benzo[k]fluoranthene & 214 & 209 & 3490 & 6200 & 6.2 \\
\hline Benzo[e]pyrene & & & & 10600 & 10.6 \\
\hline Benzo[a]pyrene & 12 & 203 & 396 & 8600 & 8.6 \\
\hline Indeno[ $[1,2,3$-cd]pyrene & 228 & 162 & & 5100 & 5.1 \\
\hline Dibenz[a,h]anthracene & 45 & 380 & 1080 & & \\
\hline Benzo[g,h,i]perylene & 347 & 424 & 378 & & \\
\hline
\end{tabular}

dichloromethane:hexane $(1 \mathrm{ml})$, dichloromethane $(2 \mathrm{ml})$ and 93:7 dichloromethane:methanol $(1 \mathrm{ml})$. Eluants of respective samples were collected (combined) in Pyrex test tubes and then evaporated to dryness under a stream of dry nitrogen. The internal standard solution mixture of 4-terphenyl- $\mathrm{d}_{14}$ and perylene- $\mathrm{d}_{12}$ was then added to each sample to obtain $1 \mathrm{ng} \mu \mathrm{l}^{-1}$ as the final concentration. Then the sample was reconstituted to a final volume of $250 \mu \mathrm{l}$ in dichloromethane:hexane (1:1). The GC/MS analyses (described below) were performed with $60 \mu \mathrm{l}$ of the reconstituted sample placed in a GC vial that had an attached conical insert (volume of $150 \mu \mathrm{l}$ ) and then capped with a screw cap with septa. The amount of PAHs in each sample was calculated from the respective calibration curves obtained with the MS quantization method described below. All glassware used in the experiments was washed and then baked at $500{ }^{\circ} \mathrm{C}$ for $24 \mathrm{~h}$, and stored in oven-baked aluminium foil. The quartz wool was also baked and stored in aluminium foil. The extraction procedure adapts steps described in the Lab Manual 2007/2008 of the Imperial College Organic Geochemistry, Imperial College London (UK) (Imperial College 2008).

\section{Headspace SPME sampling procedure}

Operating principles of SPME can be found in the monograph by Pawliszyn (1999). In this study, we have chosen a headspace non-equilibrium condition with a relatively long time-frame ( $40 \mathrm{~min})$ and slightly elevated temperature $\left(40^{\circ} \mathrm{C}\right)$ for extraction. In practice, the temperature chosen is a compromise between sensitivity and sufficiently short extraction time. Our data from liquid extraction indicated very low levels of target analytes in our samples; therefore, we allowed longer times for the SPME extractions. A few samplings of the CRM standard soils with $30 \mu \mathrm{m}$ PDMS fibres at $60^{\circ} \mathrm{C}$ showed that the $20^{\circ} \mathrm{C}$ temperature change resulted in smaller amounts of PAHs adsorbed on the PDMS fibre. Sampling at $60^{\circ} \mathrm{C}$ for 10 min with $100 \mu \mathrm{m}$ fibre, however, gave a faster analysis turnaround and amounts of PAHs adsorbed were close to that from sampling at $40^{\circ} \mathrm{C}$ for $40 \mathrm{~min}$. The smaller partitioning of PAHs into the $30 \mu \mathrm{m}$ PDMS fibre, with increasing temperature, and the uptake processes were reported by Muijs \& Jonker (2009) and they were attributed to an enthalpy change.

Soil samples were ground in an agate mortar before weighing and sampling. On average, $0.8 \mathrm{~g}$ of soil sample was weighed into a standard $2 \mathrm{ml} \mathrm{GC}$ vial, which was then sealed with a PTFE septum cap. The sample amounts of Salten Skov and standard BCR-524 soils were smaller, 0.4 and $0.3 \mathrm{~g}$, respectively. Vials were set into a heating block at $40^{\circ} \mathrm{C}$ for at least $2 \mathrm{~h}$ for thermal equilibrium to be reached throughout the sample. Afterwards, the fibre was exposed for $40 \mathrm{~min}$ to the headspace without making contact with the soil. Immediately after sampling, the fibre was inserted into the GC injector for thermal desorption and GC/MS analyses. The fibre was then left in the injector (for continuous cleaning) for $18 \mathrm{~min}$ (the entire chromatographic run) before it was removed for a new extraction. Blank injections between extractions (empty fibre) were performed to monitor possible carryover from the exposed fibre. The CRM soil standards (on average $0.95 \mathrm{~g}$ of the soil) were headspace sampled at $40^{\circ} \mathrm{C}$ for $40 \mathrm{~min}$.

\section{Instrumentation}

Analyses of SPME and liquid extraction samples were performed using a Varian GC/MS system consisting of a Saturn model 3800 gas chromatograph (injection port model 1079) that was coupled to a Saturn model 2000 ion trap mass spectrometer. A $0.25 \mathrm{~mm}$ ID $\times 30 \mathrm{~m}$ long Zebron ZB-5MS fused silica capillary column $(0.25 \mu \mathrm{m}$ film thickness $)$ (Phenomenex) was used for all GC/MS experiments. The helium carrier gas was maintained at a constant flow of 
$1 \mathrm{ml} \mathrm{min}{ }^{-1}$. The MS was operated in electron impact (EI) mode, with trap temperature set at $220^{\circ} \mathrm{C}$, transfer line at $300^{\circ} \mathrm{C}$ and manifold at $80^{\circ} \mathrm{C}$. The ion storage level for all segments was set at $55 \mathrm{~m} / \mathrm{z}$. To increase the sensitivity of our GC/MS system, the target compounds were detected in the selected segments, which were timed according to the retention times and molecular ions (Table 2) of the individual analytes. The MS data handling software included a compound table with respective retention times and mass spectra for all target analytes.

Instrument parameters for the SPME runs were as follows: the programmable injection port temperature was set to $285^{\circ} \mathrm{C}$ with the initial split set at 20:1. After the SPME fibre was introduced into the injection port, the split mode was turned off for $5 \mathrm{~min}$ (thermal desorption of analytes). After this time had elapsed, the injection port temperature was set to $250^{\circ} \mathrm{C}$ and the split was activated again and remained 20:1 for the entire run. To eliminate carryover of compounds between extractions, the fibre was left in the injection port for the entire run. The fibre depth in the injector was set at 3 on the Supelco SPME device scale; this had been optimized to allow desorption of analytes from the fibre in the hottest part of our GC injection port. The GC oven temperature was programmed as follows: $75^{\circ} \mathrm{C}$ - put on hold for $1 \mathrm{~min}$, ramped to $280^{\circ} \mathrm{C}$ at a rate of $25^{\circ} \mathrm{C} \mathrm{min}^{-1}$ and then to $300^{\circ} \mathrm{C}$ at $10^{\circ} \mathrm{C} \mathrm{min}^{-1}$ and, finally, put on hold for $3 \mathrm{~min}$. The total chromatographic run was 17.9 min long. External calibration curves were used to determine the levels of target analytes. Although the total run lasted only $\sim 18 \mathrm{~min}$, all peaks were sufficiently resolved to be positively identified by their mass fractional pattern and even by their retention times.

Instrument parameters for liquid injections were as follows: the programmable injection port temperature was set to $250^{\circ} \mathrm{C}$ with the initial split turned on (20:1). After the $0.0 \mathrm{~min}$ mark, the split mode was turned off for $1 \mathrm{~min}$. The split was activated after $1 \mathrm{~min}$ and remained at a 20:1 ratio for the entire run. Liquid samples $(1 \mu \mathrm{l})$ were injected using a Varian model 8200 auto-sampler equipped with a 48 -vial carousel. The userdefined programme of the auto-sampler included solvent flush sampling, syringe wash with dichloromethane $(20 \mathrm{~s})$, solvent plug $(0.2 \mu \mathrm{l})$, upper and lower air gap, injection rate $\left(0.2 \mu \mathrm{s} \mathrm{s}^{-1}\right)$ and needle residence time $(0.02 \mathrm{~min})$. The $\mathrm{GC}$ oven temperature was programmed as follows: $60^{\circ} \mathrm{C}$-put on hold for $1 \mathrm{~min}$, ramped to $250^{\circ} \mathrm{C}$ at rate $10^{\circ} \mathrm{C} \mathrm{min}{ }^{-1}$, ramped to $280^{\circ} \mathrm{C}$ at rate $5^{\circ} \mathrm{C} \mathrm{min}^{-1}$ and then put on hold for $4 \mathrm{~min}$. The total chromatographic run was $50 \mathrm{~min}$ long. The MS data handling included a quantification method of an internal standard calibration using 4-terphenyl- $\mathrm{d}_{14}$ and perylene- $\mathrm{d}_{12}$ as internal standards and anthracene- $\mathrm{d}_{10}$ as a surrogate compound. The calibration curves (five replicates) for each PAH were obtained for the concentration range of $0.25-2 \mathrm{ng} \mu \mathrm{l}^{-1}$.

\section{Results and discussion}

\section{Texture, $\mathrm{pH}$ and organic matter content of soil samples}

We performed tests for texture (type), $\mathrm{pH}$ and organic mass loss on all collected soil samples (Table 1). The three major categories of soil are sandy (typically comprised of approximately $80-100 \%$ sand, $0-10 \%$ silt and $0-10 \%$ clay), loam (typically comprised of approximately $25-50 \%$ sand, 30-50\%, silt and $10-30 \%$ clay) and clay (typically comprised of approximately $0-45 \%$ sand, $0-45 \%$ silt and $50-100 \%$ clay). Different proportions of sand, silt and clay give rise to different types of loam soils: sandy loam, silty loam, clay loam, sandy clay loam, silty clay loam and loam. A soil that meets the textural definition of loam, however, can lose its characteristics when it is compacted, depleted of organic matter or has clay dispersed throughout its earth fraction. Our soil samples exhibit different ratios of sand, silt and clay (Table 1). We classified samples P-2, P-8 and Salten Skov to be the 100\% silt. The highest $75 \%$ of clay was determined in sample P- 6 and $50 \%$ in sample P-5. The HOBO sample shows 50\% sand and 50\% silt, and this is in good agreement with reports on the loamy sand and loamy silt types of soils found in the vicinity of the HOBO site (Squeo et al. 2007). Analyses of Utah soil samples, including clay and mineral composition, are reported by Kotler et al. (2011).

After soils were soaked in water for $24 \mathrm{~h}$, all Utah (P), $\mathrm{HOBO}$ and Salten Skov samples showed moderately basic $\mathrm{pH}$, with the most alkaline being P-7 and P-5 at pH 10.01 and $\mathrm{pH}$ 9.28 , respectively. The $\mathrm{pH}$ dropped on average by $0.7 \mathrm{pH}$ units to constant levels after 2 weeks (Table 1). The HOBO soil was found to be slightly basic to neutral with a measured $\mathrm{pH}$ range of 7.18-7.04. The sampling site for $\mathrm{HOBO}$ was located around $60 \mathrm{~km}$ from the coast close to the Meija region $\left(\mathrm{S}-17^{\circ} 00^{\prime} \mathrm{W}-71^{\circ}\right.$ $\left.59^{\prime}\right)$ in the southern part of Peru. Alkaline soil $\mathrm{pH} 8.4$ is reported for Piura in the northern part of the Atacama Desert in southern Peru. The slightly acidic soils (pH 6.79) are in the Fray-Jorge area in north-central Chile (Squeo et al. 2007). It has been suggested that on Mars the chemical weathering processes are dominated by low $\mathrm{pH}$, acidic environment and dry deposition (Hurowitz \& McLennan 2007; Skelley et al. 2007). In contrast, Quinn \& Orenberg (1993) argue that in order to explain the results of the Viking gas exchange (GEX) experiment, the soil should be slightly to moderately basic $(\mathrm{pH}$ 7.4-8.7). Also, the recent in situ data from the Phoenix Mars lander indicate moderately alkaline ( $\mathrm{pH}$ 7.7) soil (Hecht et al. 2009). The Salten Skov soil, on the other hand, was slightly acidic with a $\mathrm{pH}$ range of $6.01-5.8$; this $\mathrm{pH}$ value is higher than that reported by Peeters et al. (2009).

The highest concentration of organic matter $(12 \%)$ was found in the Salten Skov sample. All other samples show relatively low $1-3 \%$ organic matter content except for P-8 and P-10 (4-5\%). Organic matter levels of 0.5 and 3\% are reported in soil samples from the Atacama Desert in southern Peru in the Piura and Mejia regions, respectively (Squeo et al. 2007). Navarro-Gonzalez et al. (2006) report $10-1500 \mu \mathrm{g} \mathrm{C} \mathrm{g}{ }^{-1}$ of total organic matter (TOM) in different desert soils and 20 $400 \mu \mathrm{g} \mathrm{C} \mathrm{g}^{-1}$ in Atacama soils in Chile.

\section{PAH abundance in soil samples}

There are no data available on the overall comparison of extraction procedures using different soils with variations in abiotic properties (e.g. texture, $\mathrm{pH}$ ) and $\mathrm{PAH}$ concentration 
(Song et al. 2002). In order to understand the possible relationship between the texture, $\mathrm{pH}$ and $\mathrm{PAH}$ content in our samples, we have chosen soil standards that echo those properties (Table 3). We used certified amounts of PAHs found in the European Commission BCR CRM standards for quantification of SPME sampling, efficacy of the liquid extraction procedure and calculation of the recovery of the surrogate PAH compound (anthracene- $\mathrm{d}_{10}$ ).

We used the headspace SPME/PDMS-GC/MS technique as an expedited screening method to determine the presence of PAH in our Mars analogue soil samples. We did not perform detailed studies on a fibre-headspace distribution (Havenga \& Rohwer 1999) or extensive calibration procedures (Eriksson et al. 2001). The BCR-524 soil standard was used as a crosscheck sample for the SPME and liquid extraction procedures (Table 4). The BCR-524 standard soil represents a sample of highly contaminated industrial soil with a high concentration of heavy PAHs. The heaviest compounds in molecular weight found with SPME extraction were pyrene, benz[a]anthracene, and chrysene while compounds with more than four rings were extracted via liquid extraction. These data demonstrate the limitation of the headspace SPME sampling for highmolecular-weight PAHs. In contrast to this limitation, SPME data show its high sensitivity for volatile PAHs such as twoand three-ring compounds, e.g. naphthalene, acenaphthylene, acenaphthene and fluorene. Losses of these volatile PAHs during the liquid extraction process are identified (Martens et al. 1997; Song et al. 2002), and they are reflected here in the $\%$ recovery of a three-ring surrogate, anthracene- $\mathrm{d}_{10}$ (Tables $5 \mathrm{a}$ and $5 \mathrm{~b})$. It is apparent that in order to achieve a more coherent data set, both liquid extraction and SPME methods are needed to provide complementary information. The SPME results presented in Tables $5 \mathrm{a}$ and $5 \mathrm{~b}$ are from a single calibration replicate. Data are obtained from a headspace sampling using a $100 \mu \mathrm{m}$ PDMS fibre at $40^{\circ} \mathrm{C}$ for $40 \mathrm{~min}$. Quantification of analyte concentrations is based on an external calibration method using CRM soil standards (Table 3). The amounts of PAHs measured in the soil analogue samples are very low, up to $\sim 60 \mathrm{ng} \mathrm{g}^{-1}$ at the most, and they were calculated from the extrapolation ranges of the calibration curves. Our data show that analytes that could be extracted with the headspace SPME technique, at the concentration levels present in the studied soils, are naphthalene through pyrene, except for the Salten Skov sample where even benz[a]anthracene and chrysene were detected.

Our results show that the number of aromatic rings and analyte concentration significantly influence sampling efficiency. The larger the ring formation of a polyaromatic hydrocarbon, the lower the vapour pressure and, therefore, the lower the efficacy of headspace sampling. Headspace SPME sampling of PAHs up to a four-ring structure had been previously reported by Havenga \& Rohwer (1999) and Eriksson et al. (2001), among others. While naphthalene was detected in all samples by both the SPME and liquid extraction methods, benzo[k]fluoranthene was not determined in any of the samples by either method. Anthracene was only determined in the P-1 and P-7 samples, where SPME analysis
Table 4. Detection of PAHs in the standard soil BCR-524 using SPME and liquid extraction procedures

\begin{tabular}{|c|c|c|c|}
\hline $\begin{array}{l}\text { Extraction method } \\
\text { BCR-524 soil std; sample mass (g) } \\
\text { Amount of PAH }\end{array}$ & $\begin{array}{l}\text { SPME } \\
0.2918 \\
\mu \mathrm{g} \mathrm{g}^{-1}\end{array}$ & $\begin{array}{l}\text { Liquid } \\
0.3094 \\
\mu \mathrm{g} \mathrm{g}^{-1}\end{array}$ & $\begin{array}{l}\text { Certified } \\
\text { amount } \\
\mu \mathrm{g} \mathrm{g}^{-1}\end{array}$ \\
\hline Naphthalene & 17.7 & 5.50 & . \\
\hline Acenaphthylene & 64.8 & 10.1 & \\
\hline Acenaphthene & 83.2 & 20.8 & \\
\hline Fluorene & 161 & 92.0 & \\
\hline Phenanthrene & 529 & 680 & \\
\hline Anthracene & 23.4 & 52.1 & \\
\hline Fluoranthene & 19.1 & 12.0 & \\
\hline Pyrene & 78.0 & 116.4 & 173 \\
\hline Benz[a]anthracene & 37.8 & 24.3 & 22.5 \\
\hline Chrysene & 8.20 & 10.3 & \\
\hline Benzo[b]fluoranthene & & 3.80 & 13.5 \\
\hline Benzo[k]fluoranthene & & 4.10 & 6.2 \\
\hline Benzo[a]pyrene & & 8.30 & 8.6 \\
\hline Indeno[1,2,3-cd]pyrene & & 12.2 & 5.1 \\
\hline Dibenz[a,h]anthracene & & 4.80 & \\
\hline Benzo[ghi]perylene & & 5.10 & \\
\hline Benz[e]pyrene & & 16.3 & 10.6 \\
\hline Surogate-Anthracene- $\mathrm{d}_{10} \%$ recovery & & 73.4 & \\
\hline
\end{tabular}

showed 0.3 and $0.4 \mathrm{ng} \mathrm{g}^{-1}$, respectively, and in the Salten Skov sample $\left(1.1 \mathrm{ng} \mathrm{g}^{-1}\right)$. Anthracene, however, was not found in those samples when processed with the liquid-extraction method. A high concentration $(9000 \pm 6000 \mathrm{ppm})$ of anthracene was reported in a soil sample from the Atacama Desert (Young Hill) using the Mars Organic Analyzer-Capillary Electrophoresis (MOA-CE) system. The authors, nevertheless, conclude that their result is probably an overestimate due to the experimental design (Stockton et al. 2009). Our analysis shows that when phenanthrene is present in higher quantities, careful inspection of chromatograms and manual integration need to be performed in spite of the programmed calibration of the GC/MS method. Phenanthrene and anthracene have the same quantity of ions and they elute within $10 \mathrm{~s}$.

The evidence for heavier PAHs in our samples was obtained from the liquid extraction analyses. The amounts of PAHs presented in Tables $5 \mathrm{a}$ and $5 \mathrm{~b}$ are given with the standard deviation of the results $(n=3)$, which are shown in parentheses. The recoveries of the surrogate $\mathrm{PAH}$, anthracene- $\mathrm{d}_{10}$, are also shown for each analysis. Data point towards an analysis error of $25-30 \%$ for naphthalene through fluorene and $10-15 \%$ for heavier PAHs. The recovery of the surrogate $(50-125 \%)$ in our analyses varies for different samples, but we cannot establish a relationship between sample texture, $\mathrm{pH}$ and surrogate yield. Recovery rates for the target PAHs were obtained from liquid extractions of standard soil samples (Table 3) and a liquid standard in which the concentration of each compound was $1 \mu \mathrm{g} \mathrm{ml}^{-1}$. Recoveries of naphthalene, acenaphthylene, acenaphthene and fluorene were consistently the lowest in all samples (40-60\%), while the heavier PAHs were extracted with a yield of $80-100 \%$. In contrast to headspace SPME sampling, heavier PAHs are more efficiently extracted with organic solvent. Instead, more volatile PAHs are lost due to evaporation processes involved in the liquid-extraction procedure. Our results agree with the reported data where the 
Table 5. Amounts of target PAHs detected in Mars analogue samples. Samples 'P'-analytes extracted with the SPME/PDMS; samples 'PE'-analytes extracted through liquid extraction

\begin{tabular}{|c|c|c|c|c|c|c|c|c|c|c|c|c|}
\hline (a) Sample & P-8 & PE-8 & P-7 & $\begin{array}{l}\text { PE-7 } \\
316(012)\end{array}$ & $\begin{array}{l}\text { P-6 } \\
0881\end{array}$ & PE-6 & $\begin{array}{l}\text { P-5 } \\
0750\end{array}$ & $\begin{array}{l}\text { PE-5 } \\
351(019)\end{array}$ & $\begin{array}{l}\text { P-3 } \\
0888\end{array}$ & $\begin{array}{l}\text { PE-3 } \\
3.33(0.10)\end{array}$ & $\begin{array}{l}\text { P-2 } \\
0.783\end{array}$ & $\begin{array}{l}\text { PE-2 } \\
3.33(0.17)\end{array}$ \\
\hline $\begin{array}{l}\text { Sample mass (g) } \\
\text { PAH }\end{array}$ & \multicolumn{12}{|c|}{ Amount (ng g ${ }^{-1}$ sample) } \\
\hline Naphthalene & 20 & $4.2(0.84)$ & 4.9 & $4.5(1.1)$ & 8.0 & $4.4(1.1)$ & 8.6 & $3.7(0.94)$ & 3.1 & $4.1(0.88)$ & 4.9 & $3.9(0.65)$ \\
\hline Acenaphthylene & 72 & & & & 62 & & 61 & & & & 26 & \\
\hline Acenaphthene & & $3.9(0.78)$ & & $4.0(0.85)$ & & $1.3(0.26)$ & 1.3 & $3.5(0.98)$ & & $2.5(0.52)$ & 1.7 & $3.6(0.61)$ \\
\hline Fluorene & 6.4 & $4.5(0.81)$ & 21 & $4.9(1.1)$ & 13 & $5.0(1.1)$ & & $4.0(1.0)$ & 5.5 & $4.6(0.23)$ & 13 & $4.1(0.82)$ \\
\hline Phenanthrene & & $5.5(1.1)$ & 1.8 & $4.3(0.95)$ & & $7.4(1.9)$ & 6.9 & $3.1(0.78)$ & 5.1 & $6.8(1.4)$ & 9.7 & $4.6(0.69)$ \\
\hline Anthracene & & & 0.4 & & & & & & & & & \\
\hline Fluoranthene & & $4.7(0.89)$ & & $4.7(0.89)$ & & $4.7(0.92)$ & & $4.0(0.88)$ & & $4.4(0.66)$ & 6.5 & $4.2(0.84)$ \\
\hline Pyrene & & $4.5(0.68)$ & & $4.3(0.65)$ & & $4.3(0.86)$ & & $3.7(0.55)$ & & $4.0(0.60)$ & 13 & $3.8(0.65)$ \\
\hline Benz[a]anthracene & & $6.7(0.54)$ & & $2.4(0.29)$ & & $4.2(0.63)$ & & $3.8(0.57)$ & & $6.0(1.2)$ & & $3.9(0.78)$ \\
\hline Chrysene & & $1.9(0.22)$ & & $4.2(0.50)$ & & $4.7(0.71)$ & & $4.0(0.48)$ & & $6.5(1.0)$ & & $2.0(0.26)$ \\
\hline Benzo[b]fluoranthene & & $6.1(0.91)$ & & $4.1(0.05)$ & & $4.5(0.68)$ & & $5.5(0.66)$ & & $3.7(0.44)$ & & $3.6(0.36)$ \\
\hline \multicolumn{13}{|l|}{ Benzo[k]fluoranthene } \\
\hline Benzo[a]pyrene & & $4.7(0.47)$ & & $2.0(0.28)$ & & $4.7(0.85)$ & & $1.8(0.23)$ & & $5.9(0.77)$ & & $4.1(0.62)$ \\
\hline Indeno[1,2,3-cd]pyrene & & $2.0(0.16)$ & & $3.6(0.53)$ & & $6.7(1.23)$ & & $3.9(0.62)$ & & $5.6(0.69)$ & & \\
\hline Dibenz[a,h]anthracene & & $0.90(0.018)$ & & $0.90(0.018)$ & & $1.7(0.24)$ & & & & $1.8(0.23)$ & & $0.50(0.11)$ \\
\hline Benzo[ghi]perylene & & $1.5(0.17)$ & & $4.5(0.63)$ & & $1.6(0.21)$ & & $2.9(0.46)$ & & $1.3(0.20)$ & & \\
\hline $\begin{array}{l}\text { Surrogate- Anthracene- } \mathrm{d}_{10} \\
(\% \text { recovery) }\end{array}$ & & $50 \pm 10$ & & $81 \pm 20$ & & $79 \pm 19$ & & $50 \pm 11$ & & $88 \pm 19$ & & $60 \pm 10$ \\
\hline (b) Sample & P-14 & PE-14 & P-13 & PE-13 & P-10 & PE-10 & $\mathrm{P}-1$ & PE-1 & НОВО & НОВО-Е & SKOV & SKOV-E \\
\hline Mass of sample (g) & 0.718 & $3.53(0.09)^{\mathrm{a}}$ & 0.861 & $3.21(0.14)$ & 0.657 & $3.31(0.09)$ & 0.733 & $3.23(0.16)$ & 1.38 & $3.04(0.05)$ & 0.472 & $2.43(0.13)$ \\
\hline $\mathrm{PAH}$ & \multicolumn{12}{|c|}{ Amount ( $\mathrm{ng} \mathrm{g}^{-1}$ sample) } \\
\hline Naphthalene & 5.3 & $3.9(0.97)$ & 9.2 & $4.2(0.92)$ & 9.2 & $13(2.6)$ & 12 & $4.1(1.3)$ & 3.0 & $4.5(1.1)$ & 22 & $7.4(3.0)$ \\
\hline Acenaphthylene & 13 & & 40 & & 11 & $1.7(0.37)$ & 37 & & 14 & & 8.3 & \\
\hline Acenaphthene & 1.3 & & & & 0.5 & $4.5(1.12)$ & 0.2 & $1.2(0.36)$ & 1.2 & & 2.4 & \\
\hline Fluorene & 5.4 & $4.8(1.1)$ & 6.1 & $1.5(0.33)$ & 7.1 & $6.5(1.6)$ & 3.3 & $4.4(1.3)$ & 5.5 & $5.7(1.4)$ & 8.2 & $10(2.2)$ \\
\hline Phenanthrene & 3.6 & $8.0(2.2)$ & 1.1 & $9.1(2.3)$ & 1.0 & $27(6.8)$ & 2.2 & $3.8(1.1)$ & 16 & $9.2(2.3)$ & 50 & $48(12)$ \\
\hline Anthracene & & & & & & & 0.3 & & & & 1.1 & \\
\hline Fluoranthene & 3.3 & $4.3(0.95)$ & 3.6 & $4.9(0.89)$ & 5.9 & $15(3.6)$ & 5.8 & $4.7(1.4)$ & 14 & $5.2(1.2)$ & 35 & $15(3.8)$ \\
\hline Pyrene & 4.2 & $3.8(0.57)$ & & $4.4(0.88)$ & 8.5 & $23(5.8)$ & 4.1 & $4.5(1.4)$ & 13 & $4.7(1.1)$ & 47 & $15(3.8)$ \\
\hline Benz[a]anthracene & & $1.9(0.23)$ & & $2.1(0.35)$ & & & & $6.4(1.9)$ & & $2.2(0.33)$ & 2.6 & \\
\hline Chrysene & & $5.8(0.87)$ & & $2.3(0.35)$ & & $8.1(1.6)$ & 1.1 & & & $4.7(0.75)$ & 7.8 & $3.8(0.76)$ \\
\hline Benzo[b]fluoranthene & & $1.7(0.22)$ & & $7.0(1.2)$ & & $8.3(1.7)$ & & $4.3(0.69)$ & & $4.3(0.65)$ & & \\
\hline Benzo[k]fluoranthene & & & & & & & & & & & & \\
\hline Benzo[a]pyrene & & $5.6(0.72)$ & & $4.0(0.52)$ & & & & $6.6(0.99)$ & & $2.3(0.35)$ & & $3.5(0.53)$ \\
\hline Indeno[1,2,3-cd]pyrene & & $5.7(1.02)$ & & $6.4(0.90)$ & & $2.0(0.3)$ & & & & & & $2.5(0.38)$ \\
\hline Dibenz[a,h]anthracene & & $0.60(0.072)$ & & $0.90(0.14)$ & & $2.6(0.39)$ & & & & $3.3(0.49)$ & & \\
\hline Benzo[ghi]perylene & & & & $4.8(0.49)$ & & $4.3(0.67)$ & & $6.3(0.99)$ & & $1.8(0.28)$ & & \\
\hline $\begin{array}{l}\text { Surrogate- anthracene- } \mathrm{d}_{10} \\
\text { (\% recovery) }\end{array}$ & & $125 \pm 5.0$ & & $95 \pm 10$ & & $61 \pm 12$ & & $50 \pm 16$ & & $113 \pm 2.0$ & & $70 \pm 19$ \\
\hline
\end{tabular}

${ }^{\mathrm{a}} \operatorname{STDEV}(n=3)$ given in parenthesis; all samples 'PE'. 
recovery rates range from 41 to $56 \%$ for 2- and 3-ring PAHs and from 81 to $96 \%$ for larger-ring compounds (Martens et al. 1997; Song et al. 2002). The recovery of the surrogate, anthracene- $\mathrm{d}_{10}$, was $55 \pm 5 \%$ for all standards except, for BCR-524 where it was $74 \%$. The GC/MS chromatograms of the P-13, P-10, HOBO and Salten Skov samples show additional peaks to those of target PAHs. These compounds seem to be oxygenated polyaromatic molecules with polyfunctional groups but their proper identification was not possible due to the focal point of our GC/MS method, which was targeted for PAHs.

The concentrations of PAHs in our samples are at least four orders of magnitude lower than those determined in some industrial soils polluted with coal tar and petroleum products, collected at an old gasworks, around the airport in Delhi (India) as well as from those found in sediment samples from the Niger Delta region (Havenga \& Rohwer 1999; Eriksson et al. 2001; Anyakora et al. 2005; Ray et al. 2008). The total amounts of PAHs in those samples are reported to be from 1 to $100 \mu \mathrm{g} \mathrm{g}^{-1}$ sample, which correlates to the level and duration of influx of PAH contamination in a given environment.

To the best of our knowledge there are no reports in the literature regarding the contents of PAHs in the desert soils of Utah. Atmospheric deposition is the most common source of soil contamination, and so the deposition of particulates associated with different PAH sources could result in spatial variability and enhanced levels at certain areas. PAHs may undergo adsorption, volatilization, photolysis and chemical degradation; microbial activity can be an effective catabolic process. Degradation of PAHs requires a consortium of microorganisms and the rate depends on the environmental conditions and the number and type of micro-organisms. Changes in the microbial community are still unpredictable and so, consequently, are the rates of bioremediation. The metabolic breakdown of pyrene and phenanthrene to cyclic carboxylic acids along with other functional groups within the molecules has been observed (Haritash \& Kaushik 2009). The culture-independent molecular characterization of microbial community structure and diversity has been performed on several of the samples analysed in this paper. All three domains of life (Archaea, Bacteria and Eukarya) were present, with most diversity in Bacteria. A wide variety of putative extremophiles were also observed in these analogue soils (Direito et al. 2011). A relation between the microbial distribution and the geological context (minerals and elemental composition), organic content and environmental parameters is discussed in Ehrenfreund et al. (2011), this volume.

\section{Conclusion}

In the context of Mars exploration, it is vital to obtain knowledge about the survival of organic molecules in extreme conditions. Measuring the abundance and distribution of organic matter in Mars analogue samples collected in terrestrial dry deserts is critical to our understanding of preservation. The aim of this study was to optimize the SPME method for fast screening and determination of PAHs in soil samples. Current organic detection instruments for Mars missions are specialized for small molecules and small PAHs, and therefore our analysis method is important since we optimize for small compounds. The measured concentrations of PAHs are, in general, very low, ranging from 1 to $60 \mathrm{ng} \mathrm{g}^{-1}$. We found that $100 \mu \mathrm{m}$ SPME fibres provided a better response because of the higher extraction levels compared to $30 \mu \mathrm{m}$ fibres. We noticed approximately 3-fold higher sampling efficiencies for the $100 \mu \mathrm{m}$ compared to the $30 \mu \mathrm{m}$ PDMS fibres for naphthalene through fluorene and $15 \times$ higher efficiencies for phenanthrene and larger PAHs (under similar sampling conditions). The heaviest compounds found with the SPME extraction method were pyrene, benz[a]anthracene and chrysene, while compounds with more than four rings were extracted using the liquid-extraction method. This demonstrates the limitation of headspace SPME sampling for highmolecular-weight PAHs; however, the loss of 2- and 3-ring volatile PAHs during liquid extraction is not insignificant. PAHs and organic matter constitute potential sources of carbon for growth and survival of microorganisms. However, PAHs and organic matter contents did not correlate with DNA yield or detection (Ehrenfreund et al. 2011) indicating that the levels and variety of PAHs detected were not significantly affected by microbes. SPME appears to be a rapid, viable field sampling technique with implications for use on planetary missions.

\section{Acknowledgements}

Grazyna E. Orzechowska and Pascale Ehrenfreund were supported by the NASA Astrobiology Institute (NAI). The research described in this paper was carried out at the Jet Propulsion Laboratory, California Institute of Technology, under a contract with the National Aeronautics and Space Administration. The EuroGeoMars 2009 campaign was organized and supported by the International Lunar Exploration working group (ILEWG), NASA Ames Research Center and ESA/ESTEC. We acknowledge the contribution of the EuroGeoMars 2009 campaign crew and the mission support team.

\section{References}

Anyakora, C., Ogbeche, A., Palmer, P., Coker, H., Ukpo, G. \& Ogah, C. (2005). GC/MS analysis of polynuclear aromatic hydrocarbons in sediment samples from the Niger Delta region. Chemosphere 60, 990-997.

Agency for Toxic Substances and Disease Registry (ATSDR) (1995). Toxicological profile for Polycyclic Aromatic Hydrocarbons (PAHs). Atlanta, GA: U.S. Department of Health and Human Services, Public Health Service.

Benner, S.A., Devine, K.G., Matveeva, L.N. \& Powell, D.H. (2000). The missing organic molecules on Mars. Proc. Natl. Acad. Sci. U.S.A. 97, 2425-2430.

Berlardi, R.G. \& Pawliszyn, J. (1989). The application of chemically modified fused silica fibers in the extraction of organics from water matrix samples and their rapid transfer to capillary columns. Water Pollut. Res. J. Can. 24, 179-186.

Biemann, K. \& Lavoie, J.M. (1979). Some final conclusions and supporting experiments related to the search for organic compounds on the surface of Mars. J. Geophys. Res. 84, 8385-8390. 
Biemann, K., Oro, J., Toulmin, P., Orgel, L.E., Nier, A.O., Anderson, D.M., Simmonds, P.G., Flory, D., Diaz, A.V., Rushneck, D.R. et al. (1976). Search for organic and volatile inorganic compounds in two surface samples from the Chryse Planitia region of Mars. Science 194, 72-76.

Direito, S.O.L., Ehrenfreund, P., Mareas, A., Staats, M., Foing, B.H. \& Roling, W.F.M. (2011). A wide variety of extremophiles and large betadiversity at the Mars Desert Research Station (Utah). Int. J. Astrobiol. 10, 191-207.

Edwards, N.T. (1983). Polycyclic aromatic hydrocarbons (PAHs) in the terrestrial environment - a review. J. Environ. Qual. 12, 427-441.

Ehrenfreund, P., Röling, W.F.M., Thiel, C., Quinn, R., Septhon, M.A., Stoker, C., Direito, S.O.L., Kotler, M., Martins, Z., Orzechowska, G.E., Kidd, R.D. \& Foing, B.H. (2011). Astrobiolgy and habitability studies in preparation for future Mars missions: trends from investigating minerals, organics and biota. Int. J. Astrobiol. 10, 239-253.

Eriksson, M., Faldt, J., Dalhammar, G. \& Borg-Karlson, A.K. (2001). Determination of hydrocarbons in old creosote contaminated soil using headspace solid phase microextraction and GC-MS. Chemosphere 44, 1641-1648.

Fillmore, R. (2000). The Geology of the Parks, Monuments and Wildlands of Southern Utah. University of Utah Press, Salt Lake City.

Grote, C. \& Pawliszyn, J. (1997). Solid-phase microextraction for the analysis of human breath. Anal. Chem. 69, 587-596.

Hansen, A.A., Merrison, J.P., Nornberg, P., Lomstein, B.A. \& Finster, K. (2005). Activity and stability of complex bacterial soil community under simulated Martian conditions. Int. J. Astrobiol. 4, 135-144.

Haritash, A.K. \& Kaushik, C.P. (2009). Biodegradation aspects of polycyclic aromatic hydrocarbons (PAHs): a review. J. Hazard. Mater. 169, 1-15.

Havenga, W.J. \& Rohwer, E.R. (1999). Chemical characterization and screening of hydrocarbon pollution in industrial soils by headspace solidphase microextraction. J. Chromatogr. A 848, 279-295.

Hecht, M.H., Kounaves, S.P., Quinn, R.C., West, S.J., Young, S.M.M., Ming, D.W., Catling, D.C., Clark, B.C., Boynton, W.V., Hoffman, J. et al. (2009). Detection of perchlorate and the soluble chemistry of Martian soil at the Phoenix lander site. Science 325, 64-67.

Hurowitz, J.A. \& McLennan, S.M. (2007). A similar to 3.5 Ga record of water-limited, acidic weathering conditions on Mars. Earth Planet. Sci. Lett. 260, 432-443.

Imperial College, London (2008). Lab Manual; Soil Extraction Procedure, Imperial College Organic Geochemistry. Imperial College, London.

Jia, M.Y., Koziel, J. \& Pawliszyn, J. (2000). Fast field sampling/sample preparation and quantification of volatile organic compounds in indoor air by solid-phase microextraction and portable gas chromatography. Field Anal. Chem. Tech. 4, 73-84.

Kataoka, H., Lord, H.L. \& Pawliszyn, J. (2000). Applications of solid-phase microextraction in food analysis. J. Chromatogr. A 880, 35-62.

Kotler, M., Martins, Z., Foing, B.H. \& Ehrenfreund, P. (2011). Analysis of the mineral matrix of planetary soil analogs from the Utah desert. Int. J. Astrobiol. 10, 221-229.

Lord, H. \& Pawliszyn, J. (2000). Evolution of solid-phase microextraction technology. J. Chromatogr. A 885, 153-193.

Martens, D., Maguhn, J., Spitzauer, P. \& Kettrup, A. (1997). Occurrence and distribution of polycyclic aromatic hydrocarbons (PAHs) in an agricultural ecosystem. Fresenius J. Anal. Chem. 359, 546-554.

McKay, C.P. (1997). The search for life on Mars. Orig. Life Evol. Biosphere 27, 263-289.

McKay, D.S., Gibson, E.K., Thomas-Keprta, K.L., Vali, H., Romanek, C.S., Clemett, S.J., Chillier, X.D.F., Maechling, C.R. \& Zare, R.N. (1996). Search for past life on Mars: Possible relic biogenic activity in Martian meteorite ALH84001. Science 273, 924-930.

Merrison, J., Jensen, J., Kinch, K., Mugford, R. \& Nornberg, P. (2004). The electrical properties of Mars analogue dust. Planet. Space Sci. 52, 279-290.

Muijs, B. \& Jonker, M.T.O. (2009). Temperature-dependent bioaccumulation of polycyclic aromatic hydrocarbons. Environ. Sci. Tech. 43, 4517-4523.
Navarro-Gonzalez, R., Navarro, K.F., de la Rosa, J., Iniguez, E., Molina, P., Miranda, L.D., Morales, P., Cienfuegos, E., Coll, P., Raulin, F. et al. (2006). The limitations on organic detection in Mars-like soils by thermal volatilization-gas chromatography-MS and their implications for the Viking results. Proc. Natl. Acad. Sci. U.S.A. 103, 16089-16094.

Nornberg, P., Schwertmann, U., Stanjek, H., Andersen, T. \& Gunnlaugsson, H.P. (2004). Mineralogy of a burned soil compared with four anomalously red Quaternary deposits in Denmark. Clay Miner. 39, $85-98$.

Orzechowska, G.E. \& Paulson, S.E. (2005). Photochemical sources of organic acids. 1. Reaction of ozone with isoprene, propene, and 2-butenes under dry and humid conditions using SPME. J. Phys. Chem. A 109, 53585365.

Pawliszyn, J., Ed. (1999). Applications of Solid Phase Microextraction. RSC Chormatography Monographs. RSC, Cambridge.

Pawliszyn, J. (2000). Theory of solid-phase microextraction. J. Chromatogr. Sci. 38, 270-278.

Pawliszyn, J. \& Martos, P. (1997). Air analysis by solid phase microextraction. Abstracts of Papers ACS 214, 187-ANYL.

Peeters, Z., Quinn, R., Martins, Z., Sephton, M.A., Becker, L., van Loosdrecht, M.C.M., Brucato, J., Grunthaner, F. \& Ehrenfreund, P. (2009). Habitability on planetary surfaces: interdisciplinary preparation phase for future Mars missions. Int. J. Astrobiol. 8, 301-315.

Quinn, R.C. \& Orenberg, J. (1993). Simulations of the Viking gas exchange experiment using palagonite and $\mathrm{Fe}$-rich montmorillonite as terrestrial analogs: implications for the surface composition of Mars. Geochim. Cosmochim. Acta 57, 4611-4618.

Ray, S., Khillare, P.S., Agarwal, T. \& Shridhar, V. (2008). Assessment of PAHs in soil around the international airport in Delhi, India. J. Hazard. Mater. 156, 9-16.

Seiferlin, K., Ehrenfreund, P., Garry, J., Gunderson, K., Hutter, E., Kargl, G., Maturilli, A. \& Merrison, J.P. (2008). Simulating Martian regolith in the laboratory. Planet. Space Sci. 56, 2009-2025.

Sephton, M.A. \& Botta, O. (2005). Recognizing life in the Solar System: guidance from meteoritic organic matter. Int. J. Astrobiol., 4, 269-276.

Skelley, A.M., Aubrey, A.D., Willis, P.A., Amashukeli, X., Ehrenfreund, P., Bada, J.L., Grunthaner, F.J. \& Mathies, R.A. (2007). Organic amine biomarker detection in the Yungay region of the Atacama Desert with the Urey instrument. J. Geophys. Res. 112, G04S11, doi:10.1029/ 2006JG000329.

Song, Y.F., Jing, X., Fleischmann, S. \& Wilke, B.M. (2002). Comparative study of extraction methods for the determination of PAHs from contaminated soils and sediments. Chemosphere 48, 993-1001.

Squeo, F.A., Holmgren, M., Jimenez, M., Alban, L., Reyes, J. \& Gutierrez, J. R. (2007). Tree establishment along an ENSO experimental gradient in the Atacama desert. J. Vegetation Sci. 18, 195-202.

Stockton, A.M., Chiesl, T.N., Scherer, J.R. \& Mathies, R.A. (2009). Polycyclic aromatic hydrocarbon analysis with the Mars organic analyzer microchip capillary electrophoresis system. Anal. Chem. 81, 790-796.

Supelco (2008). European Commission BCR Information Reference Materials-CRM 524.

Tielens, A. (2008). Interstellar polycyclic aromatic hydrocarbon molecules. Annu. Rev. Astron. Astrophys. 46, 289-337.

Williams, P.L. \& Hackman, R.J. (1971). Geology of the Salina Quadrangle, Utah; Misc. geologic investigations, Map I-591-A, 1971.

Wu, J.C., Xie, W. \& Pawliszyn, J. (2000). Automated in-tube solid phase microextraction coupled with HPLC-ES-MS for the determination of catechins and caffeine in tea. Analyst 125, 2216-2222.

Zent, A.P. \& McKay, C.P. (1994). The chemical reactivity of the Martian soil and implications for future missions. Icarus 108, 146-157.

Zolotov, M. \& Shock, E. (1999). Abiotic synthesis of polycyclic aromatic hydrocarbons on Mars. J. Geophys. Res. - Planets 104, 1403314049 . 